\title{
KUALITAS PELAYANAN PAJAK KENDARAAN BERMOTOR DAN BEA BALIK NAMA KENDARAAN DI KANTOR SAMSAT KOTA PALANGKA RAYA PROVINSI KALIMANTAN TENGAH
}

\author{
The Quality Of Service Of Motor Vehicle Tax And The Return Of Vehicle Name \\ In The Office Of Samsat City Palangka Central Kalimantan Province
}

\section{Shanty Bahar Ising* \\ Novi Damayanti}

Universitas Muhammadiyah Palangkaraya, Palangka Raya,

Central Kalimantan, Indonesia

email:

shanty.bahar@umpalangkaraya.ac.id

\section{Kata Kunci:}

Kualitas Pelayanan

Pajak

Bea

Balik Nama

Kendaraan Bermotor

\section{Keywords:}

Quality of Service

Tax

Customs

Behind the name

Motor vehicles

\section{Accepted}

January 2015

\begin{abstract}
Abstrak
Penelitian ini bertujuan untuk mengetahui, mendeskripsikan dan menganalisis tentang Kualitas Pelayanan Pajak Kendaraan Bermotor dan Bea Balik Nama (PKB dan BBNKB) di Kantor SAMSAT Kota Palangka Raya Provinsi Kalimantan Tengah. Metode yang digunakan adalah eksplanatif kualitatif, penelitian yang dilakukan merupakan penelitian deskriptif dimana SAMSAT (Sistem Administrasi Manunggala Satu Atap) Kota Palangka Raya dipilih sebagai lokasi penelitian.Teknik Pengumpulan Data menggunakan : wawancara, dokumentasi, dan observasi.

Berdasarkan hasil penelitian bahwa kualitas pelayanan pajak kendaraan bermotor dan bea balik nama kendaraan bermotor (PKB dan BBNKB) di Kota Palangka Raya Provinsi Kalimantan Tengah. Terkait ketepatan waktu tunggu sudah baik, petugas bekerja sesuai dengan jam yang ditentukan dan terkait waktu tunggu proses tergantung dari kesiapan persyaratan pemohon, namun berdasarkan wawancara penelitian dengan masyarakat bahwa untuk waktu proses masih kurang baik dapat di nilai dari pelayanan cepat yang tidak melalui tahapan-tahapan yang sudah ditentukan.
\end{abstract}

Published

April 2015

\section{PENDAHULUAN}

Pada hakekatnya tugas pokok pemerintah sebagai organisasi publik adalah memberikan pelayanan kepada masyarakar, sehingga aparat pemerintah memiliki kewajiban dan tanggung jawab untuk memberikan pelayanan publik dengan baik dan dapat memuaskan semua pihak. Terselenggaranya pelayanan publik yang profesional merupakan tanggung jawab bersama antara pemerintah dan masyarakat, karena mendapatkan pelayanan yang memuaskan merupakan hak masyarakat yang harus dipenuhi oleh pemerintah. Salah satu organisasi publik yang berhubungan langsung dengan pelayanan publik adalah SAMSAT. Organisasi ini 
bertugas melayani masyarakat dalam hal pembayaran, pajak kendaraan bermotor dan bea balik nama kendaraan bermotor (PKB dan BBNKB). Mengingat pentingnya sektor pajak kendaraan bermotor dan BBNKB dalam rangka pembangunan nasional, maka aparat pemerintah perlu memberikan pelayanan semaksimal mungkin dan memuaskan kepada wajib pajak.

Adapun yang terjadi menurut observasi di kantor SAMSAT mengalami keluhan dari masyarakat, dalam kepengurusan masih banyak oknum yang menawarkan jasa dalam proses yang cepat terkait pada pajak kendaraan bermotor dan bea balik nama kendaraan bermotor, sehingga masyarakat belum merasa puas dengan kualitas pelayanan kantor SAMSAT kota Palangka Raya. Sedangkan SAMSAT sebagai organisasi publik dituntut untuk melayani masyarakat sebagai wajib pajak sebaik mungkin dan dapat memuaskan wajib pajak, tetapi pada kenyataanya pelayanan SAMSAT belum dapat memuaskan wajib pajak, mulai dari adanya pungutan liar yang mudah ditemukan disekitar kantor SAMSAT Kota Palangka Raya, lamanya waktu pelayanan serta masih minimnya sarana prasarana yang ada. Sehingga membuat masyarakat enggan untuk membayar pajak akibatnya banyak yang mengalami penunggakan.

\section{Kualitas Pelayanan}

Menurut Parasuraman (Hutasoit ,201 I:66) Kaulitas Pelayanan adalah perbedaan antara pelayanan yang diharapkan dengan pelayanan yang terima. Ciri-ciri atau atribut tersebut Tjiptono (Hardiansyah,20 I0:40) antara lain adalah :

I. Ketepatan waktu pelayanan, yang meliputi waktu tunggu dan waktu proses.

2. Akurasi pelayanan yang meliputi bebas dari kesalahan

3. Kesopanan dan keramahan dalam memberikan pelayanan
4. Kemudahan mendapatkan pelayanan, misalnya banyaknya petugas yang melayani dan banyaknya fasilitas pendukung seperti komputer

5. Kenyamanan dalam memperoleh pelayanan, berkaitan dengan lokasi, dengan lokasi, ruang tempat pelayanan, tempat parkir, ketersedian informasi dan lain-lain.

6. Atribut pendukung pelayanan lainnya seperti ruang tunggu ber AC, kebersihan dan lain-lain.

\section{Pelayanan Pajak Kendaraan Bermotor dan Bea Balik Nama (PKB dan BBNKB) Kantor SAMSAT Kota Palangka Raya}

SAMAT merupakan organisasi publik yang memberikan pelayanan dalam hal pajak kendaraan bermotor dan pajak bea balik nama kendaraan bermotor. Dua jenis ini mempunyai nilai finansial yang cukup besar, maka tak heran jika para wajib pajak menuntut haknya untuk memperoleh pelayanan yang cepat dan memuaskan. Wajib pajak sebagai objekpajak berhak menuntut apa yang menjadi haknya yaitu menuntut adanya pelayanan yang cepat dan memuaskan karena telah memenuhi kewajibannya untuk membayar Pajak Kendaraan Bemotor Maupun Bea Balik Nama Kendaraan Bermotor (PKB maupun BBNKB).

\section{METODOLOGI}

Pendekatan yang digunakan mencapai tujuan dari penelitian ini adalah pendekatan kualitatif yang bersifat eksplanatif yakni suatu penelitian yang ditunjukan untuk menjelaskan kesatuan penyebab gejala yang dipertanyakan serta mengindentifikasi kegiatan sebab akibat mungkin gejala tersebut merujuk pada pendapat (Bugin 2013:122). Peneliti ini untuk memahami lebih mendalam tentang kualitas pelayanan pajak kendaraan bermotor dan bea balik nama kendaraan bermotor (PKB dan BBNKB) Di kantor SAMSAT Kota Palangka Raya Provinsi Kalimantan Tengah, adapun alasan peneliti menggunakan metode kualitatif karena 
permasalahanpun belum jelas, sehingga perlu di dukung oleh teori-teori.

\section{HASIL DAN PEMBAHASAN}

Berdasarkan yang di dapat dari hasil penelitian seuai dengan infikator kualitas pelayanan pada Kantor Samsat di Bidang Pajak Kendaraan Bermotor dan Bea Balik Nama Bermotor di Kota Palangka Raya dijelaskan sebagai berikut :

I. Ketepatan waktu pelayanan, yang meliputi waktu tunggu dan waktu proses.

Terkait ketepatan waktu, waktu tunggu dan waktu proses di kantor SAMSAT Kota Palangka Raya. Untuk ketepatan waktu kinerja sudah sesuai dengan jam kerja yang ditentukan, dan mengenai waktu proses tergantung dari kesiapan persyaratan pemohon sebagai wajib pajak dan kinerja dari petugas wajib pajak itu sendiri. Tetapi dapat di nilai dari beberapa wawancara dengan masyarakat waktu tunggu masih kurang maksimal dikarena dari kinerja petugas yang lambat dan masyarakat pun mengambil jalan pintas dengan menggunakan jasa calo.

2. Akurasi Pelayanan, yang meliputi bebas dari kesalahan

Terkait akurasi pelayanan, seharusnya petugas lebih teliti dalam memproses permohonan yang diajukan oleh wajib pajak sehingga tidak terjadi kesalahan contohnya pada pengetikan naam, alamt, jenis kendaraan dan lain-lain. Dikarenakan masih ada dari beberapa keluhan masyarakat yang mengalami kesalahan dalam menerima hasil dari pelayanan pihak SAMSAT, untuk tindakan yang diberikan dari pihak SAMSAT sudah cukup bertanggung jawab dengan cara memperbaiki ulang atas kesalahan yang di berikan kepada wajib pajak.

3. Kesopanan dan Keramahan dalam memberikan pelayanan

Terkaitan sikap kesopanan dan keramah di kantor SAMSAT sudah baik dapat dilihat dari pakaian petugas yang rapi dan sopan sesuai dengan pakian dinas yang sudah ditentukan. Dalam melayani masyarakat petugas juga sudah memberikan pelayanan sesuai dengan nomor urut antarian demi kelancaran pelayanan yang teratur dan rapi. Adanya komunikasi yang baik antara wajib pajak dan petugas dapat mempercepat waktu penyelesaian. Dengan memposisikan wahib pajak sebagai pihak yang harus dilayanai dengan baik, petugas SAMSAT senantiasa memberikan perhatian yang bersifat individual dan tulus kepada wajib pajak yang membutuhkan bantuan dari informasi terkait dengan pelayanan.

4. Kemudahan mendapatkan pelayanan, misalnya banyaknya petugas yang melayani dan banyaknya fasilitas pendukung seperti komputer.

Kemudahan dalam mendapatkan pelayanan di kantor SAMSAT Kota Palangka Raya sudah baik, bagi masyarakat yang berkepentingan dalam mengurus PKB dan BBNKB, SAMSAT sudah menyediakan dari berbagai macam fasilitas salah satunya adalah Kendaraan SAMSAT keliling yang ada di Palangka Raya hal ini dilakukan agar mempermudah wajib pajak dalam mendapatkan pelayanan, namun berdasarkan wawancara dengan masyarakat untuk kendaraan SAMSAT keliling ini masih belum optimal dalam pelaksanaanya, dikarenakan hanya ada pada hari-hari tertentu.

5. Kenyamanan dalam memperoleh pelayanan, berkaitan dengan lokasi ruang parkir, ketersedian informasi dan lain-lain.

Dari hasil penelitian terkait kenyamanan masyarakat dalam memperoleh pelayanan sudah cukup baik dari segi ruangan khusus yang sudah tersedia. Semua masyarakat menggunakan tempat yang berbeda sesuai dengan kepentingannya, namun kesediaan fasilitas untuk masyarakt masih kurang memadai seperti tempat parkir yang tidak beraturan antara petugas dengan masyarakat 
masih berada pada satu tempat khususnnya kendaraan bermotor.

6. Artibut pendukung pelayanan lainnya

Terkait dengan atribut pendukung yang terserdia di kantor SAMSAT dalam memberikan pelayanan kepada masyarakat, petugas menyediakan ruang tunggu bagi masyarakat sesuai dengan kepentingannya disertai fasilitas yang sudah memadai. Namun dari segi keistimewaan masih kurang karena dari penggunaan $A C$ hanya untuk ruangan bagi petugas saja. Pihak SAMSAT juga menyediakan petugas kebersihan agar ruangan terlihat rapi dan bersih. Serta penyediaan kartu antrian dari pihak petugas digunkana tergantung dari banyaknnya masyrakat yang erkepentingan, atribut lengkap berupa tanda pengenal masih kurang optimal karena hanya digunakan oleh beberapa tugas.

\section{KESIMPULAN}

Berdasarkan dari hasil penelitian secara kualitatif mengenai kualitas pelayanan Pajak Kendaraan Bermotor Dan Bea Balik Nama Kendaraan Bermotor (PKB dan BBNKB) di kantor SAMSAT Kota Palangka Raya sudah cukup baik dan masih ada beberapa kekurangan dalam pelayanan khususnya pada kaulitas pelaksanaanya. Penulis mengajukan beberapa saran yang diharapkan dapat berguna untuk peningkatan kualitas pelayanan yang selama ini telah diberikan oleh SAMSAT Kota Palangka Raya kepada wajib pajak peneliti menyarankan beberapa hal sebagai berikut :

I. Diharapkan dari pihak Kantor SAMSAT Kota Palangka Raya harus lebih teliti dalam memberikan pelayanan dengan fasilitas yang sudah memadai agar masyarakat lebih percaya kepada pihak petugas.

2. Diharapkan kepada pimpinan UPT-PPD kota palangka raya untuk melaksanakan pengawasan yang lebih ketat agar pelayanan yang diberikan kepada masyarakat sesuai dengan SOP yang ada
3. Diharapkan untuk kantor SAMSAT Kota Palangka Raya lebih memaksimalkan pelayanan kendaraan SAMSAT kelilin agar masyarakat lebih mudah memperoleh pelayanan pajak.

\section{REFERENSI}

Agustino, Leo. 2012. Dasar-Dasar Kebijakan Publik. Bandung : cv. Alfabeta.

Ali. Faried. 201I. Teori Konsep administrasi dari pemikiran paradikamtik menuju redaksi. Makasar : PT.Rajagrafindo

Bungil Burhan. 2013. Metode penelitian sosial dan ekonomi. Jakarta timur : Media Pustaka.

Dunn, William N. 2003. Pengantar Analisis Kebijakan Publik. Yogyakarta : Gadjah Mada Universitas Press.

Hardiansyah. 20I0. Kualitas Pelayanan Publik. Bandung : PPs Unpad.

Hutasoit. 20II. Pelayanan public teori dan aplikasi. Jakarta Timur : MAGMA Script Publishing.

Melong Lexy J. 2007. Teori Administrasi Publik. Bandung : CV Alfabeta.

Pasolong. Harbani. 2007. Teori Administrasi Publik. Bandung : CV Alfabeta.

Saputra, Jaya. 2014. Profil kantor samsat dan Dispenda Provinsi Kalimantan Tengah .

Sodang, S. 2002. Sistem Informasi Manajemen. Jakarta : Sinar Grafika Offsiet.

Subarsono, AG. 2005. Analisis Kebijakan Publik : Konsep teori dan aplikasi. Yogyakarta : Pustaka Belajar.

Suyanto, Bagong dan Sutinah. 2005. Metodelogi penelitian sosial. Jakarta : Prenada Media. 